\title{
Application of RASCH Models to Validate Emotional Intelligence Inventory (EII) in High School Students
}

\author{
Mulawarman Mulawarman* \\ Department of Guidance and \\ Counseling \\ Faculty of Education, Universitas \\ Negeri Semarang \\ Semarang, Indonesia \\ mulawarman@mail.unnes.ac.id*
}

\author{
Binti Isrofin \\ Department of Guidance and \\ Counseling \\ Faculty of Education, Universitas \\ Negeri Semarang \\ Semarang, Indonesia \\ bintiisrofin@mail.unnes.ac.id
}

\author{
Afriyadi Sofyan \\ Department of Guidance and \\ Counseling \\ Faculty of Education, Universitas \\ Negeri Semarang \\ Semarang, Indonesia \\ afriyadisofyan@mail.unnes.ac.id
}

\begin{abstract}
This study aims to validate the Emotional Intelligence Inventory (EII) using the Rasch Model. The research sample of 394 senior high school students (SMK and MAN) in the city of Semarang. The sample selection using cluster random sampling techniques. The results of this study showed that from 54 item to be 34 items fit use the Rasch measurement model with acceptable fit index (0.66 -1.49). Further analysis showed item reliability of 0.99 and person reliability of 0.77 . This research proved that EII can be used as a measurement tool for emotional intelligence in senior high school context.
\end{abstract}

Keywords—emotional intelligence, Rasch model

\section{INTRODUCTION}

Industrial Era 4.0 demands higher quality human resources, namely people who are not only superior in terms of their rationality but also have an emotional advantage. Research conducted by psychologists shows that rational intelligence or intelligence contributes approximately $20 \%$ to a person's success, while $80 \%$ is determine by other forces including emotional intelligence [1]. In the theory of multiple intelligence suggests that there are seven intelligence possessed by humans. Among the seven intelligences related to emotional intelligence is interpersonal intelligence.

Salovey and Mayer proposed definition of emotional intelligence as an emotional information processing that includes accurate appraisal of emotions in one-self and others, appropriate expression of emotion, and adaptive regulation of emotion in such a way as to enhance living [2]. Emotional intelligence is the ability of emotions to control themselves, have endurance when faced with problem, motive themselves, able to regulate moods, the ability to empathize and foster relationships with others [3]

Emotional intelligence works in synergy with cognitive skills. Based on the results show that there is a significant positive correlation between the level of emotional intelligence with the learning achievement of second grade high school students [4]. Thus, it can be interpreted that the higher the level of emotional intelligence of high school students, the higher the learning achievement will be. The other research by Chamundeswari [5] that there is a significant correlation between emotional intelligence with academic achievement of student. Other research shows that whether students learn or not is also influenced by emotions, so the teachers by helping students to understand their emotions can be useful to support the learning process [6]. This shows that emotional intelligence significantly influences student learning outcomes [7].

In addition to being influential in the academic field, emotional intelligence also influences individual decision making and leadership attitudes [8, 9]. Research conducted by Aprilia [10] shows that there is a negative correlation between emotional intelligence and brawl behavior in adolescent boys who have been involved in brawls at SMK "B" Jakarta. Arbadiati in Yulianto [11] said that individuals who have intelligence have the ability to feel emotions, manage and utilize emotions appropriately so as to provide convenience in living life as a social creature.

For middle school adolescents, emotional intelligence has an important role. This emotional aspect is very important needed because it will truly understand the personal reality itself and that exists in the surrounding environment. In addition to this emotional aspect students / individuals learn to deal with conflicts and effective challenges, in the sense that students need efforts to build emotional intelligence in order to control their feelings and channel them in positive and productive ways. Based on the search results, in Indonesia only found two emotional intelligence instruments developed by Syamsu [12] and Wulandari [13]. The two elements were developed using the classical test theory approach. Wibisono as cited in Ardiyanti [14] argued that $95 \%$ of measurements in psychological studies are still being developed based on the classical test theory (CTT) approach. In classical test theory the attitude measurement is considered as interval data so that the data can be directly processed in the formula. Meanwhile, Mitchel as cited in Ardiyanti [14] also argued that the type of data obtained through measurement techniques that ask for opinions or 
attitudes, is nominal and ordinal so that analytical tools that can be used are also limited. Even this classical test theory approach was later improved by the emergence of item response theory (IRT). One approach model in IRT is the Rasch model.

Therefore, this study aims to validate Emotional Intelligence Iinventory using Rasch modeling with the help of computer programming WINSTEPS 4.4.5 [15, 16]. Bond and Fox [15] stated that the use of the Rasch model in instrument validation would produce more holistic information about the instrument and better meet the measurement definition. This statement was supported by Sumintono and Widhiarso [17] that argues for the advantages of Rasch modeling compared to other methods, especially classical test theory, namely the capacity to predict missing data. These advantages puts Rasch model above other methods in its' accuracy. Additionally, Rasch modelling is able to produce standard error measurement values for the instruments used which can improve the accuracy of the calculations. Calibration is carried out in Rasch modelling simultaneously in three ways, namely the scale of measurement, respondent (person), and item (item).

\section{METHODS}

Emotional Intelligence Inventory (EII) is a 54 item inventory based on Salovey \& Mayer's five dimensions of emotional intelligence: knowledge of one's emotion, ability to control emotion, ability to motivate oneself, knowledge of other's emotion and foster relationships with others developed by Mulawarman [18] with 5 dimensions. Respondents in this study were 394 students of high school or its' equivalent in Semarang. The sampling was done using cluster random sampling techniques [19].

The Emotional Intelligence Inventory (EII) employs Likert scaling that uses a continuum of "always", "often", "sometimes", "rarely" and "never". For favourable statements, "always" is scored as 5 and "never" was scored as 1 . Reversely, for unfavourable statements, "always" was scored as 1 and "never" was scored as 5. This study employs summated Ratings method to weigh the values [20]. Researchers used the WINSTEP Rasch Model computer program $4.4 .5[15,16]$ to analyse the information regarding response misfit can be accessed via link https://osf.io/q5c92/.

\section{RESULT AND DISCUSSION}

\section{A. Checking Data Item and Person to Objective Measurement}

This research conducts two preliminary checks to decide accurating the data items and respondents taking are according to the ideal measurement model. The ideal item and person suitability that the researcher took is determined by the measurement range value in Outfit Mean Squared (MNSQ) which is 0.5 logit $<$ MNSQ < 1.5 logit; The standard Z Outfit (ZSTD) is $-2.0<$ ZSTD $<+2[10,9,13]$. Based on item analysis, from a total of 54 items there were 20 items that were outliers or misfit. This meaning that 20 items were not able to measure what should be measured or items that were made difficult for respondents to understand. Information fit items can be accessed via the link https://osf.io/rz7xw/. At the person level researchers found that of the 394 people who filled EII there were 86 respondents who were inconsistent or were not serious about filling EII or did not understand the item well. Detailed information regarding response misfit can be accessed via link https://osf.io/q5c92/.

\section{B. Reliability Test: Item and Person}

Reliability explain how far the measurements made made many times will produce the same information. This means that it does not produce a lot of significant differences in information [17]. This research did reliability test to carried out through three processes, namely by looking at the reliability of items, reliability of people and the reliability of interactions between people and items when filling EII. Table. 1 showed summary statistic from Rasch model analyze [21].

Table. 1 Summary Statistic of reliability test estimation $(\mathrm{N}=$ 308)

\begin{tabular}{|l|c|}
\hline \multicolumn{1}{|c|}{ Estimatision } & Measure \\
\hline Person reliability & .77 \\
\hline Items reliability & .99 \\
\hline Cronbach Alpha (KR-20) person raw score test reliability & .81 \\
\hline Item separation index & 9,38 \\
\hline Person separation index & 1.82 \\
\hline
\end{tabular}

datapoints: 10694. Log-likelihood chi-squared: 23968.6279 with approximately $24000+-19$ d.f., probability $=.0558$. Global Root-Mean-Square Residual: .7867 .

Based on the table 1, it can be seen that the appropriate of the answers given by person or person reliability (.77) is 'adequately' while and the reliability of the items in the emotional intelligence inventory (.99) results are "excellent". While the interaction between person and item as a whole (.81) 'Good'. Thus, EII can be used to measure by considering doing rapport on the respondent so that respondents are really serious in filling.

\section{Threshold: Partial Credit Model}

In this study, the researcher analyzes the validity of the rating scale to verify whether the ranking (choice) of the choice used confuses respondents or not.

Tabel 2. Summary of Category Structure. Model="R" (N = 308)

\begin{tabular}{|c|c|c|c|}
\hline Label & $\begin{array}{c}\text { Category } \\
\text { Label }\end{array}$ & $\begin{array}{c}\text { Observed } \\
\text { Average }\end{array}$ & $\begin{array}{c}\text { Andrich } \\
\text { Threshold }\end{array}$ \\
\hline Never & 1 & -.69 & None \\
\hline Rarely & 2 & .00 & -1.87 \\
\hline Sometimes & 3 & .77 & -.81 \\
\hline Often & 4 & 1.31 & .34 \\
\hline Very often & 5 & 1.94 & 2.34 \\
\hline
\end{tabular}

In the table. 2 can be seen that the average observation starts from logit -.69 for the choice of score 1, then the choice with a score of 2 is .00 logit and increases to logit + 1.31 for a score of 4 , and +1.94 for the choice of score 5 . Logit value for each option showing improvement, this shows that respondents can ascertain the difference between the choice of answers provided in the EII. The average value of observations is relevant to the value of Andrich Threshold which moves monotonically from NONE then moves toward a negative logit and continues to lead to a 
positive logit for each answer choice indicating that the given answer choice is declared valid (NONE $->-1.87$ logit $\rightarrow-.81$ logit $\rightarrow .34$ logit $\rightarrow+2.34$ logit). Thus, it can be concluded that the suitability between items and the choice of answers is ideal for measurement.

\section{Estimation Validity Through Principal Component Analysis}

Unidimensional test using Principal Component Analysis (PCA). Aims to measure the diversity of instruments measuring what should be measured in this case is an inventory of emotional intelligence.

Table 3. Standardized Residual Variance (in Eigen value Units) $(\mathrm{N}=308)$ [21]

\begin{tabular}{|l|c|c|}
\hline & Observed & Expected \\
\hline Total raw variance in observations & $100.0 \%$ & $100.0 \%$ \\
\hline Raw variance explained by measures & $34.0 \%$ & $35.1 \%$ \\
\hline Raw variance explained by persons & $5.9 \%$ & $6.1 \%$ \\
\hline Raw Variance explained by items & $28.1 \%$ & $29.0 \%$ \\
\hline Raw unexplained variance (total) & $66.0 \%$ & $64.9 \%$ \\
\hline Unexplained variance in 1st contrast & $5.1 \%$ & $7.8 \%$ \\
\hline Unexplained variance in 2nd contrast & $4.4 \%$ & $6.6 \%$ \\
\hline Unexplained variance in 3rd contrast & $4.0 \%$ & $6.0 \%$ \\
\hline Unexplained variance in 4th contrast & $3.7 \%$ & $5.6 \%$ \\
\hline Unexplained variance in 5th contrast & $2.7 \%$ & $4.1 \%$ \\
\hline
\end{tabular}

Based on the table, it can be seen that the results of the measurement of raw variance data amounted to $34 \%$ (> $20 \%$ ). Thus, it can be concluded that the inventory of emotional intelligence meets unidimensionality.

\section{E. Item Measure}

One of the advantages of using Rasch Model for researchers is being able to provide a linear scale with the same interval. Item measures provide information about the items that are the most difficult to approve by the person and the items that are the easiest to approve.

Based on table 4 , item 1 logit value with value $(+2.11$ logit) shows this is the item that is the most difficult to agree with the respondent in the given EII instrument; while item no. 2 with a value (- 1.73 logit) is the method that is most easily agreed upon by respondents.

\section{F. Person Measure}

Person Measure provides information about each person's logit. Detailed information regarding person measures can be accessed via link https://osf.io/kqt3a/. based on a person measure analysis of 308 researchers found that person 48 showed the highest emotional intelligence compared to others $(+2.90)$. while person 144 shows the lowest emotional intelligence by answering in the direction of never.

Tabel 4. Item Measure of EII (Item $=34, \mathrm{~N}=308)$

\begin{tabular}{|c|c|c|}
\hline Item No & Measure & Perceived \\
\hline 1 & 2.11 & Difficulties \\
\hline 5 & 1.60 & \\
\hline 16 & 1.49 & \\
\hline 6 & .77 & \\
\hline 34 & .71 & \\
\hline 9 & .61 & \\
\hline 21 & .51 & \\
\hline 8 & .33 & \\
\hline 15 & .29 & \\
\hline 18 & .26 & \\
\hline 11 & .25 & \\
\hline 7 & .10 & \\
\hline 17 & .10 & \\
\hline 10 & .01 & \\
\hline 20 & -.06 & \\
\hline 30 & -.11 & \\
\hline 12 & -.13 & \\
\hline 4 & -.26 & \\
\hline 25 & -.28 & \\
\hline 31 & -.32 & \\
\hline 29 & -.33 & \\
\hline 19 & -.33 & \\
\hline 26 & -.40 & \\
\hline 28 & -.44 & \\
\hline 3 & -.49 & \\
\hline 14 & -.49 & \\
\hline 13 & -.51 & \\
\hline 24 & -.52 & \\
\hline 33 & -.53 & \\
\hline 32 & -.55 & \\
\hline 22 & -.59 & \\
\hline 27 & -.64 & 1 \\
\hline 23 & -.73 & \\
\hline 2 & -1.73 & Easiest \\
\hline
\end{tabular}

\section{CONCLUSION}

Based on the data from this study, researcher conclude that the Emotional Intelligence Inventory has a very good item reliability, only for sufficient person reliability. For validity through PCA $34 \%$ (> 20\%) is fulfilled. Limitation this research responden taked in semarang. To get good results, the EII needs to be followed up with continuing development both in terms of writing the statement items, the number of statement items, the contents of the statement to the subjects used in developing the Emotional Intelligence Inventory.

\section{REFERENCES}

[1] Goleman, D. Emotional Intelegence: Mengapa EI Lebih Penting daripada IQ. Jakarta: PT Gramedia Pustaka Utama, 1998,pp. 44

[2] P. Salovey, \& J.D. Mayer, Emotional Intelligence, dalam http://unh.edu/emotional_intelligence/EIAssets/-

EmotionalIntelligenceProper/EI1990_Emotional_Imagination, Cognition, and Personality).

[3] Daniel Goleman, Emotional Intelligence Why It Can Matter More Than IQ, (New York: Bantam Books, 1995.

[4] Hariyani, S. Hubungan Antara Masalah-Masalah yang Dihadapi dan Kecerdasan Emosional dengan Prestasi Belajar Siswa Kelas 2 SMU Negeri 3 Kediri. Skripsi Tidak diterbitkan. Malang: Jurusan PPB-FIP IKIP Malang.1999. 
[5] Chamundeswari, S. Emotional intelligence and academic achievement among students at the higher secondary level. International Journal of Academic Research in Economics and Management Sciences, 2013, 2.4: 178

[6] Campbell, Linda., Campbell, Bruce, dan Dickinson, Dee,. Teaching \& Learning Through Multiple Intelligences. Massachusetts: Allyn and Bacon. 1996.

[7] Muzdalifah, Muzdalifah. Pengaruh Kecerdasan Intelektual, Kecerdasan Emosional, dan Kecerdasan Spiritual Terhadap Hasil Belajar IPA Siswa SMP Negeri di Kabupaten Sinjai. Diss. Pascasarjana, 2017.

[8] Hess, James, and Arnold Bacigalupo. "Applying emotional intelligence skills to leadership and decision making in non-profit organizations." Administrative Sciences 3.4 (2013): 202-220.

[9] Chauhan, Richa. "Role of Emotional Intelligence in Decision Making." Available at SSRN 2797345 (2016).

[10] Aprilia, Nuri; Indrijati, Herdina. Hubungan antara kecerdasan emosi dengan perilaku tawuran pada remaja laki-laki yang pernah terlibat tawuran di SMK'B'Jakarta. Jurnal psikologi pendidikan dan perkembangan, 2014, 3.1: 1-11.

[11] Yulianto, Dema. Hubungan antara Konsep Diri dan Kecerdasan Emosi dengan Kenakalan Remaja. Nusantara of Research, 2014, 1.1.

[12] Syamsu Yusuf, L. N.; Akhmad, Sudaryat Nurdin; Adriany, Vina. Pengembangan Alat Ukur Kecerdasan Emosi Berbasis Komputer Untuk Validasi Pengambilan Keputusan Dalam Manajemen Sdm. insight, 2008, 88.
[13] Wulandari, Rina. Uji Validitas Alat Ukur Kecerdasan Emosi (The Emotional Competence Inventory 2.0). Jurnal Pengukuran Psikologi dan Pendidikan Indonesia (JP3I), 2019, 2.8.

[14] Ardiyanti, D. (2016). Aplikasi Model Rasch pada Pengembangan Skala Efikasi Diri dalam Pengambilan Keputusan Karir Siswa. Jurnal Psikologi, 43(3), 248-263.

[15] Linacre, J. M. Winsteps ${ }^{\circledR}$ Rasch measurement computer program. Beaverton, Oregon: Winsteps.com, 2019.

[16] Linacre, J. M. Winsteps ${ }^{\circledR}$ Rasch measurement computer program User's Guide. Beaverton, Oregon: Winsteps.com, 2019.

[17] Sumintono B and Widhiarso W, 2014 Aplikasi model Rasch untuk penelitian ilmu-ilmu sosial (edisi revisi) Trim Komunikata Publishing House.

[18] Mulwarman, Pengembangan Inventori Kecerdasan Emosional Siswa Sekolah Menengah Atas. 2011.

[19] Borg, Walter \& Gall, Meredith. Educational Reseach. New York: Longman. 1983.

[20] Edwards, L, Allen. Techniques Of Attitude Scale Construction. New York: Appleton Century Croft, Inc, 1957

[21] Rangka, I. B., Prasetyaningtyas, W. E., Ifdil, I., Ardi, Z., Suranata, K., Winingsih, E., ... \& Wijaya, R. S. (2018, November). Measuring psychometric properties of the Indonesian version of the NoMoPhobia Questionnaire (NMPQ): insight from Rasch measurement tool. In Journal of Physics: Conference Series (Vol. 1114, No. 1, p. 012127). IOP Publishing. 